\title{
HACIA UNA NUEVA CANCIÓN DE SOLEDAD: COPLA FLAMENCA Y CANCIÓN ESPAÑOLA
}

\section{Towards a New Song of Solitude: Copla Flamenca and Spanish Song}

Inés María LuNA

Doctora Universidad de Sevilla

inesmarialuna2@gmail.com

Recibido: 10/03/2019; Aceptado: 05/02/2020; Publicado: 31/12/2021

Ref. Bibl. INÉS MARÍA LUNA. HACIA UNA NUEVA CANCIÓN DE SOLEDAD:

COPLA FLAMENCA Y CANCIÓN ESPAÑOLA. 1616: Anuario de Literatura Comparada, 11 (2021), 59-76

RESUMEN: La visión intimista de lo popular que muestran los poetas románticos y modernistas convierte la copla flamenca en una nueva canción de soledad. Esta nace como expresión verdaderamente romántica, con características de la poesía moderna y del arte de fin de siglo. Configurada por el modernismo, manifiesta más tarde una gran influencia en la canción orquestada de los años veinte y contribuye a transformar el cuplé, de tradición decimonónica, en una nueva canción andaluza. Se desarrolla un camino de estilización que culmina en la canción española de los años treinta, con el protagonismo de Rafael de León. Desde presupuestos filológicos y estéticos analizamos en este artículo cómo la canción española es heredera de la concepción espiritual de la copla flamenca y de la cultura flamenca generada por el modernismo.

Palabras clave: modernismo; flamenco; canción española; zambra; canción de soledad; Rafael de León. 


\begin{abstract}
The intimate vision of the popular that the romantic and modernist poets show converts the flamenco copla into a new song of solitude. This song was born as a truly romantic expression, with essential characteristics of modern poetry and the art of the end of the century. Shaped by modernism, it manifests later a great influence on the orchestrated song of the twenties and contributes to transform the cuplé, of nineteenth-century tradition, into a new Andalusian song. It develops a stylization path that culminates in the Spanish song of the thirties, with the prominence of Rafael de León. From philological and aesthetic presuppositions, we analyze in this article how the Spanish song is inherited from the spiritual conception of the flamenco copla and the flamenco culture generated by modernism.
\end{abstract}

Key words: modernism; flamenco; Spanish song; zambra; song of solitude; Rafael de León.

\title{
1. INTRODUCCIÓN
}

Cuando lo andaluz comienza a contemplarse desde la tristeza, la poesía flamenca se configura definitivamente como canción de soledad. Tal hecho ocurre al acomodarse nuestro sentir a la sensibilidad romántica, unidas en la copla andaluza las inquietudes estéticas y las inquietudes populares. El flamenco llega a la soledad a través del Romanticismo y recupera un tono melancólico y unos modos de expresión característicos de la lírica tradicional. La copla flamenca se presenta como camino de expresión del desamparo, una dimensión existencial a la que no va a resultar ajena la canción española. Es importante la labor realizada desde distintas manifestaciones artísticas, pero alcanza una extraordinaria relevancia la mirada de algunos escritores y poetas.

Es conocido que Gustavo Adolfo Bécquer inaugura desde una óptica moderna la concepción romántica de lo popular. La sintonía de sentimiento y canción tradicional, sencillez y tristeza constituye lo esencialmente poético. Nos hallamos ante una tradición que se identifica sobre todo con los cantares andaluces. Bécquer transmite algo revelador de estos cantos: su poder existencial y de consolación ${ }^{1}$. La tradición popular se convierte en renovadora de la expresión culta, como demuestra en sus Rimas, que son consideradas por Juan Ramón como peteneras y soleares $(2010,128)^{2}$. Este tratamiento intimista cobra un gran protagonismo en la Colección de

1. Recuérdese la reseña a La Soledad de Augusto Ferrán, 1861.

2. Son las palabras dedicadas a Bécquer y recogidas en Alerta. 
cantes flamencos de Antonio Machado y Álvarez, 1881. Demófilo establece las características de estos cantos, ya cantes flamencos, desde una perspectiva claramente romántica. La poesía flamenca es expresión profunda de la individualidad y la melancolía, la cual se asocia al sentir gitano. La copla flamenca es, por excelencia, un cantar de soledad (Rodríguez Baltanás 2004, 577). Así se pone de relieve en el prólogo y en la selección de coplas que realiza. Como hemos tratado en otros textos (Luna 2012), no se ha tenido en cuenta suficientemente esta sintonía que la Colección de cantes flamencos, aunque él no lo declare de manera explícita, mantiene con la mentalidad del Romanticismo. Demófilo pone de relieve la expresión dolorosa e íntima del sentimiento, la conciencia de un arte nacido para conmover. Se trata de un camino de dignificación de la expresión popular que, unido a la influencia del krausismo y a las ideas institucionistas, va a tener un amplio desarrollo en la obra de Juan Ramón Jiménez, así como de Antonio y Manuel Machado.

Es precisamente Manuel Machado quien configura de forma plena los rasgos característicos de este nuevo cantar de soledad. Otorga a la copla flamenca, con la unión de modernismo y popularismo, un sentido profundamente elegíaco, sobre todo a partir de la publicación de Cante hondo en 1912. Desde esta relectura de la canción popular la tradición simbolista adquiere nuevos matices. El poeta sevillano insiste en el carácter nocturno del cante y en la fatalidad femenina, imágenes que serán trascendentales en el universo artístico de Julio Romero de Torres.

Más tarde Federico García Lorca continúa el camino de renovación poética a través de la lírica popular. Desarrolla las características de la poesía flamenca desde una mirada absolutamente romántica. Lorca establece una distinción crucial desde el punto de vista estético: la distinción de cante flamenco y cante jondo. Con él se modela la copla flamenca de manera definitiva, pues queda conformada en sus escritos como pura expresión de soledad. Aunque no responda a criterios históricos, supone un gran acontecimiento la creación de un espacio mítico de lo jondo (Maurer 2000, 47), es decir, la proyección sobre la poesía flamenca de una dimensión universal y atemporal. Destacamos el carácter nocturno de estos cantos, con la herencia literaria de Manuel Machado, la desnudez del paisaje, la importancia del llanto o la identificación de la mujer con la pena. Sobresalen el dolor y la muerte como rasgos esenciales de nuestra cultura (García Lorca 1933). De esta manera, queda unida la tristeza andaluza a la tradición española de la melancolía. Pero su reivindicación va mucho más lejos. La crítica valora el sentido mítico y universal que por primera vez logra la tristeza andaluza.

Este camino de reinterpretación artística que lleva a cabo la literatura escrita se concreta en un alejamiento del flamenco de la cultura teatral, de 
la realidad profesional, y en un alejamiento de un género que a finales del XIX ya es denominado cuplé. Como es sabido, el cuplé, que resulta heredero, a pesar de las influencias foráneas, de la tradición casticista decimonónica, comienza a ser considerado expresión de decadencia de la cultura popular $^{3}$. Es un distanciamiento de la realidad costumbrista que va a ser fundamental en la conformación de la copla flamenca y en el nacimiento de una estética del flamenco.

Hemos de decir, sin embargo, que, a pesar de esta búsqueda idealizada de cultura popular, el flamenco sigue presente en los escenarios teatrales. Con el declive de los cafés cantantes, muchos cantaores se refugian en el mundo del cuplé y de las variedades. Interpretan este género orquestal, pero no se olvidan de la expresión andaluza. Comienza la orquestación de los cantes flamencos. Debemos considerar la relevancia de intérpretes como Pastora Imperio, Emilia Benito, Amalia Molina, Antonio Grau Dauset, la Argentinita, y, por otro lado, el alcance de unos creadores, que, en su búsqueda de cultura nacional, realizan una labor de conservación y divulgación de las canciones regionales. Lo andaluz sigue logrando un gran protagonismo. Y no solo entre autores de esta procedencia.

En tal contexto de mestizaje, el cuplé recibe, en principio, la influencia de las músicas flamencas. Peteneras, zambras, farrucas, soleares, músicas flamencas con letras que en los inicios del siglo xx aún resultan demasiado apegadas al casticismo decimonónico. No obstante, conforme pasan los años y nos vamos acercando a la segunda década del siglo, la copla flamenca, que ha sido configurada por el modernismo, comienza a adquirir cada vez mayor importancia en la creación de estas canciones. La canción constituye un desarrollo narrativo de la copla popular. De esta manera, el cuplé, de tradición casticista, se va transformando poco a poco en una nueva canción andaluza especialmente melancólica ${ }^{4}$. En relación con esto, no podemos dejar de lado que muchos de los autores de los años veinte, aunque cercanos al mundo teatral, la zarzuela o la revista, también son herederos de la concepción espiritual de la copla que defiende el movimiento folclorista sevillano de finales del XIX, tan relevante en la conformación

3. Muy reveladoras son las palabras de GarCía LorCa (1922, 1281): «Puede decirse que cada día que pasa cae una hoja del admirable árbol lírico andaluz, los viejos se llevan al sepulcro tesoros inapreciables de las pasadas generaciones, y la avalancha grosera y estúpida de los cuplés enturbia el delicioso ambiente popular de toda España».

4. Es un proceso que evidencia fielmente la canción Cruz de mayo, con letra de Salvador Valverde y música de Manuel Font de Anta, 1921. 
estética del flamenco. Hablamos especialmente de Manuel y José Font de Anta, Salvador Valverde o Joaquín Guichot Barrera 5 .

Este camino de sobriedad que sigue la canción andaluza continúa en los años treinta. Se inicia una nueva etapa que nos conduce al nacimiento de la canción española. En estos años encontramos un contexto muy favorable. Podemos hablar de la consolidación definitiva de lo flamenco, de una especial conciencia de la tradición andaluza como creación de lo español y de la conformación de las propuestas estéticas del modernismo en todas las artes. En este sentido, también la canción española puede ser considerada un fruto de la llamada Edad de Plata de nuestra cultura. Ocurre, además, un hecho de especial trascendencia: la canción andaluza va a encontrarse con el poeta que le otorga sus caracteres decisivos, el poeta sevillano Rafael de León, una figura de extraordinaria sensibilidad popular, heredero de la concepción elegíaca de la copla flamenca, del imaginario artístico de Julio Romero de Torres y cercano a las propuestas estéticas de Federico García Lorca.

Así, en los años treinta, en pleno auge de la expresión neopopular y de la generación del 27 , es decir, en un contexto de renovación poética a partir de lo andaluz, Rafael de León, con la complicidad del poeta Salvador Valverde y con la música de Manuel Quiroga, estiliza a través del flamenco el costumbrismo de la canción andaluza. Esta labor se lleva a cabo particularmente en el género de la zambra. Dicho estilo recibe la herencia musical del flamenco, pero también el mundo espiritual y poético de la copla. Canciones como "Manolo Reyes", "Salomé", "María de la O" y, sobre todo, Ojos verdes revelan una orientación distinta, afianzan los rasgos característicos de esta nueva canción andaluza que comenzaba a fraguarse en los años veinte. A partir de ahora la zambra sigue un camino de dramatización del flamenco que conforma tanto en los escenarios como en el cine la estética modernista de este género.

Podemos decir que, a pesar de la fuerte tendencia a la construcción narrativa y a la permanencia de estereotipos costumbristas, la canción va adoptando unos ideales estéticos ligados al flamenco, sin los cuales su evolución hacia la canción española habría sido distinta. Se une, por tanto, a las imágenes que la cultura flamenca ha generado como expresión moderna y que constituyen el punto de partida de nuestro análisis comparativo: la noche, la sublimación del dolor y la mujer como ideal artístico.

5. Resulta significativo que uno de los principales creadores de la canción andaluza sea hijo de Alejandro Guichot y Sierra, representante fundamental del movimiento folclorista sevillano, una anécdota que ejemplifica cómo estas dos generaciones se unen de forma absolutamente natural. 


\section{LAS RAZONES DE LA NOCHE NO SON LAS DEL DÍA}

La canción española desarrolla el motivo romántico del hombre en la noche con su dolor, el cual le llega a través de la copla flamenca. Pero este se proyecta ahora en la mujer, a la que se representa como un ser enclaustrado, según la imagen tradicional de la melancolía femenina. Son muchas las canciones que nos hablan de la espera y el insomnio, como demuestran "A ciegas", "Los tientos del reloj" O "Elvira la cantaora». Como creaciones románticas, suponen la aceptación de la vigilia como estado natural, el dolor como un medio privilegiado de conocimiento. Es importante el motivo del espacio cerrado: la sala o el cuarto. La mujer se muestra en estos espacios cerrados absolutamente estática. Pero no se trata solo de un lugar físico. El espacio representa un estado de conciencia en que la voluntad se pierde. Es un estado del alma, un paisaje similar al que describe Litvak en la pintura de Regoyos, Rusiñol o Ramón Casas (2004, 61). También Manuel Machado recrea la espera de la mujer en la alcoba en un ambiente nocturno o vespertino. La amante es sobre todo consciente de su soledad. La calle y la esquina pueden convertirse, como en la poesía flamenca, en un espacio absolutamente claustrofóbico. La mente del enamorado es cuarto cerrado. Hay ocasiones en que se menciona la sala o el cuarto. En otras no se menciona, pero tenemos conciencia de un mundo cerrado, dominado por la oscuridad. Es un espacio de violencia en el que están presentes el sufrimiento y la culpa. Existe una identificación absoluta entre el espacio y la amante, una interiorización del paisaje, aunque aquí se trate de entorno urbano, y no de la relación de hombre y naturaleza.

Este dolor de la mujer en la noche se relaciona de manera esencial con el cante jondo, como vemos en "Dolores la Petenera" o "Elvira la cantaora". La amante que sufre canta coplas flamencas. La amante siempre es una cantaora $^{6}$. Se trata de una unión muy evidente entre noche, dolor, soledad y cante jondo, íntimamente asociada con el modernismo, con la espiritualización del cante, que nos devuelve a un simbolismo tradicional que relaciona la expresión del dolor con la mujer y el canto, propio de nuestra tradición oral desde las jarchas. La presencia del flamenco en la canción española crea siempre un estado de ánimo que predispone a la melancolía y a la oscuridad. El cante se une a la tristeza femenina. Hay una progresiva unión entre el cante y la mujer, a la que contribuye la canción española. Ella se convierte en dolor y cante, en expresión de lo nocturno. Este

6. "Qué te pasa, Ruiseñora? / Que tengo un nido de pena y celos en la garganta, / que hasta el corazón me llora / por seguiriyas, por soleares y por tarantas». "La Ruiseñora». 
vínculo se muestra en la obra teatral de los Machado La Lola se va a los puertos, y cobra una gran relevancia en la pintura simbolista, sobre todo en Julio Romero de Torres; en las creaciones literarias de Federico García Lorca; en Rafael Cansinos Assens, y, muy pronto, también en el cine.

La unión de mujer y cante no habría sido posible sin la importancia que adquiere en el siglo XIx la figura de la heroína trágica. El Romanticismo es la época de exaltación de la mujer. Resulta muy elocuente la conexión que establece Bécquer entre mujer y poesía, presente en su creación poética y, de manera particular, en Cartas literarias a una mujer. Todo este camino de tristeza femenina y cante jondo muestra una gran trascendencia en la canción española. En ella no solo encontramos la herencia de la poesía flamenca, sino también el universo estético que el modernismo ha creado acerca de la mujer y acerca del flamenco.

Muy relacionadas con lo nocturno estarían las imágenes que suponen un estado de angostura mental, la imposibilidad de avanzar del que ama. Esta oscuridad se expresa en la canción española como cárcel, ceguera o locura. Son estados del alma que se confunden, imágenes del rapto, de la pérdida de voluntad en que se halla el que ama.

El amor se contempla como una prisión que se manifiesta, principalmente, en los motivos de la "calle» o la "puerta cerrada»" La calle no es solo el espacio físico, es el espejo del alma. Tienen este sentido de «enclaves para el milagro", como los denomina Cenizo en la poesía flamenca (2005, 33). Como "enclaves para el milagro", son también espacios de sufrimiento. El sentimiento se materializa, aspecto que relacionamos con la tendencia realista de la cultura española, más presente aún en la cultura popular. Destaca el valor simbólico del cabello, o motivos como el cordel y la cadena. La idea del lazo implica la prisión, la fatalidad. El cabello, como imagen arquetípica del lazo, es un motivo asociado en la tradición cultural al erotismo, pero también a la melancolía y a la muerte (Durand 2005, 111). El cabello, sobre todo el cabello negro, alcanza unos niveles de fatalidad en la canción española que debemos relacionar con el carácter que adquiere en el arte simbolista. Es un motivo unido al lazo, a la atadura, a palabras como "ahogar» o "cordel», como también ocurre en la poesía flamenca.

Encontramos, por otro lado, muchos ejemplos que aluden a la soledad como ceguera9. Lo que es oscuro es irracional, la ceguera es expresión de la conciencia caída. El que entra en el dominio amoroso se encuentra en

7. Nos servimos de las palabras de Ortega en Estudios sobre el amor.

8. "Callejuela sin salida", "Carcelero, carcelero" o "El cariño que te tengo".

9. «El día que nací yo», "Tientos del reloj», «En una esquina cualquiera», "A tu vera», etc. 
otro estado de conciencia, en un estado de oscuridad aceptado libremente. Esta situación de irrealidad que crea el amor en el Romanticismo se confunde fácilmente con la locura (Argullol 2008, 421). La locura es expresión de soledad del ser que ama, estado de abandono de sí mismo. Pero también es un dolor querido. La imagen explícita de la locura de amor, importante en la literatura desde la antigüedad grecolatina y que llega a su expresión culminante en la cultura romántica, cobra protagonismo sobre todo a partir de la poesía trovadoresca. Con el paso del tiempo León Hebreo nos explica que el amor nunca es gobernado por la razón. En la canción española existe una voluntad de dolor que recuerda a la tradición trovadoresca. Pero ahora cambia el sujeto amante. La canción es importante como creación de un discurso femenino. En muy pocos textos de nuestra cultura se presenta la voz de la mujer tomando el control de su destino y eligiendo libremente este camino de locura y deseo. Hay una relación con las antiguas heroínas de la tragedia griega y las voces de la poesía medieval peninsular, la voz femenina de las jarchas o de las cantigas de amigo. Pero debemos contemplar a estas mujeres sobre todo a la luz del pensamiento romántico. Se insiste en la amante solitaria, incomprendida, que asume por voluntad propia todos los riesgos de la pasión amorosa, y que se presenta como un modelo de heroísmo para las demás mujeres.

En algunos ejemplos se menciona la locura de manera explícita. Predominan, sin embargo, aquellos que no la nombran, en los que la amante es una mujer enclaustrada, que abandona todo por amor, y que, en este amor tan total que siente, adquiere unas características cercanas a la patología. No olvidemos el gusto simbolista por la enfermedad y la belleza mórbida (Praz 1999). La mujer es el ser melancólico por naturaleza. Es la amante de "A ciegas", "Y sin embargo te quiero", "Elvira la cantaora» O "La Ruiseñora». Existe, por otro lado, frente a esta mujer encerrada, también una mujer errante, motivo heredado de la copla flamenca. Es importante esta relación de locura y nomadismo. Porque la heroína romántica debe ser una obsesionada nómada. La amante camina por las calles y las esquinas, espacios de alto carácter simbólico. Lo podemos ver en canciones como «Tatuaje», "La guapa, guapa», "Mañana sale», «En una esquina cualquiera» o "Dolores la Golondrina». Rafael Cansinos Assens establece, en este sentido, una relación muy significativa entre el carácter errante y la locura que devora tanto a los hombres como a las mujeres de la copla andaluza: «Refuerza el sentido a la parábola de las vírgenes locas, y exalta, no a las que mantienen encendida la lámpara hasta la llegada del esposo, sino a las que, impacientes y ávidas, se lanzan con ella a los caminos" $(1933,64)$.

Las imágenes de locura son muy frecuentes en los textos flamencos. El amor presenta una naturaleza de patología e irracionalidad. La locura se 
expresa de manera muy diversa, pero, como nos dice León Hebreo, tiene que ver casi siempre con el estado de abandono. La locura es consecuencia del sufrimiento, pero también es un refugio, una manifestación de la alienación romántica. El amante siente la necesidad de desdoblarse, de contemplarse a sí mismo como un ser extraño y desconocido. Se acepta, como en la canción española, que el amor es siempre un estado de desorden. Esta circunstancia se asocia en muchas ocasiones al nomadismo. El loco nómada simboliza al enamorado que ha perdido el dominio de su cuerpo y de su mente ${ }^{10}$. Creemos, como sostiene Argullol, que el héroe romántico es un obsesionado nómada. Diríamos que el enamorado también lo es. El loco enamorado está siempre en movimiento, es un ser errante. Por ello son tan importantes las calles y las esquinas. La calle, como en la canción española, presenta un destacado sentido simbólico. Se relaciona especialmente con la locura.

Pero la noche es también el sueño. La noche crea una realidad propia, una realidad de ensueño, placer y sensualidad que concluye con el día. Es el espacio en que el hombre se reconoce. En la noche solitaria nos salva el sueño. Existe una gran tradición de este tema en nuestra lírica amorosa. Es el sueño como consuelo, como entrada a lo irracional, a lo onírico, que tanta trascendencia tiene en la poesía romántica y en la cultura del Simbolismo.

Predomina en la canción española un estado de ensoñación que se extiende al día. El que ama elige vivir el sueño como la vida. El amor se vive siempre desde el sueño. La amante, consciente de su dolor, decide refugiarse en este estado de duermevela en que el tiempo se dilata ${ }^{11}$. Evoca la imagen femenina de los ojos cerrados tan característica de la pintura simbolista, expresión muy clara de la pérdida de voluntad. "El mundo irreal es verosímilmente un mundo femenino» (De Paz 1992, 194). También la mujer andaluza es imaginada desde el sueño y la tristeza, como nos recuerda la pintura de Julio Romero de Torres o de Santiago Rusiñol. Sin embargo, la luz llega y nos evoca de nuevo connotaciones de oscuridad y desamparo. Supone la irrupción brusca del tiempo, el despertar de la condición de sonambulismo propia del enamorado ${ }^{12}$.

En la copla flamenca sobresalen los ejemplos que manifiestan la ruptura súbita del sueño. El alba es dolor porque despierta al amante de su

10. «De noche y a oscuras / salí del lugá / y perdíto me veo por los campos / sin poder andá».

11. «¿i estaré, mi Dios, soñando / y tendré que despertar? / Lo que a mí me está pasando / no es mentira ni verdad». "Me embrujaste». Recuérdense también "A ciegas", "Callejuela sin salida» o "Yo no me quiero enterar».

12. «No sé qué mano cristiana abrió una mañana / mi puerta de repente, / luz que cortó en mil pedazos, como un navajazo, / mi venda de la frente». "A ciegas». 
refugio y abandono en la noche. Es un sentir muy propio de la expresión romántica. El sueño es ausencia de tiempo, como nos dice Reyes Cano a propósito de Gustavo Adolfo Bécquer (2007, 135). La luz aumenta el dolor que el hombre ya siente. El alba lo despierta, no de su placer, sino de su recogimiento en el dolor, de su abandono, y se presenta como certeza irremediable. Como en la canción española, hay un despertar de la condición de sonambulismo. Pero el flamenco insiste en el momento justo en que aparece el tiempo y el dolor se ensancha.

\section{PORQUe TODA SOLEDAD HA SIDO SENTIDA COMO UN PECADO}

Tanto la canción como el flamenco muestran la unión paradójica de libertad y olvido irremediable de uno mismo. En la imposibilidad del amor, en la melancolía alcanza este su sentido. Encontramos una expresión de contradicción, de luz y de sombra: la lucha, el esfuerzo por escapar del sufrimiento. Es un camino que finalmente lleva al que ama a aceptar una condición ineludible. Es el amante quien elige su propia fatalidad.

Desde la contradicción caminamos de manera ascendente a la aceptación total del sufrimiento. El dolor se expresa en imágenes de violencia, castigo y caída. La soledad constituye una herida, una falta que implica una penitencia. Existe una concepción de culpabilidad y pecado en el sentimiento amoroso, pero también un sentido de voluptuosidad, de recreación en este castigo de la carne. El que ama desea ser castigado. En la canción se vulnera el cuerpo de la mujer; en la copla flamenca, el del hombre.

Esta atracción por el martirio está muy relacionada con el afán de disolución que tiene el amante en la cultura modernista. Como se sabe, la relación de erotismo y violencia es una de las características esenciales de la cultura de finales del XIX. El erotismo como sacrificio es constante en el arte simbolista. Pueden recordarse las recreaciones de Gustave Moreau, Gustave Klimt y Oscar Wilde del mito de Salomé; la atracción de la época por la historia de Judith, o la concepción de la mujer como pecado en las pinturas de Von Stuck. Este Eros sacrificado, unión de lo sacro y lo profano, se evidencia en la cultura hispánica en la poesía de Rubén Darío, en algunos personajes de Azorín, las Sonatas de Valle (Litvak 1979) o las pinturas de Romero de Torres.

El deseo imperioso de seguir este destino se manifiesta en muchos ejemplos de la canción española ${ }^{13}$. La sumisión y el dominio son la respues-

13. Pueden considerarse "Dime que me quieres", "Te lo juro yo» o «Tientos del reloj». 
ta a la transgresión y el castigo. Es la imagen de quien escoge la pasión como modo de vida. Destaca el uso del imperativo, el futuro con valor de obligación o la primera persona como presencia de la voluntad. Conforme la mujer escoge este destino amoroso, va sufriendo el desgaste y martirio de su cuerpo. Solo se concibe el erotismo como violencia. El dolor del amor debe reflejarse en el cuerpo. Llama la atención la voluntad imperiosa de realizar este sacrificio, incluso, la actitud de enfrentamiento y desafío que mantiene con el amado. Actitud de desafío, pero no de desprecio.

En relación con este propósito, el imaginario religioso muestra una gran presencia en la copla flamenca y, por consiguiente, en la canción española. Predominan los siguientes motivos: la mujer penitente o mártir, la mujer en cruz, el fuego y la imagen del hierro clavado, constante en nuestra tradición poética. Se trata siempre de aspectos que ponen de relieve el castigo del cuerpo. Son motivos de gran realismo que la canción española toma de la expresión flamenca ${ }^{14}$.

Así, en los textos flamencos el amor se une de manera esencial al dolor del cuerpo. Tiene una gran importancia el amor como enfermedad. Es una manifestación esencialmente física. Quizás no existe en nuestra tradición poética una concepción tan física del sufrimiento. Se evidencia, como en la canción española, que la aceptación del destino amoroso implica el sacrificio del cuerpo. Pero hay una insistencia mayor en la carne. La carne es el símbolo del sacrificio. Sobresalen las imágenes relacionadas con la caída ${ }^{15}$. El imaginario flamenco nos presenta al ser humano como ser sin equilibrio, como ser que lucha por la verticalidad ${ }^{16}$. La expresión flamenca supone una recreación propia del mito de Sísifo ${ }^{17}$. Es conocida la preferencia de la época romántica por los mitos que evocan el sufrimiento. La caída se une a la condición temporal del hombre, y esta condición se ve simbolizada por la carne (Durand 2005, 122).

El deseo de libertad conduce definitivamente al amante a pensar en la muerte, motivo constante en el flamenco y la canción española, que une de nuevo estos textos a una larga tradición literaria. Como nos dice Carlos Gurméndez (1994, 65), la soledad, el sufrimiento de un amor no

14. Resulta elocuente la copla «Por dinero no lo jagas, / yébame a una jerrería / y échame un jierro a la cara».

15. "Que no pueo con más, / que las carnes de mi cuerpo, / a cachitos se me van".

16. «Por la callecita iba / y me tenía que pará / por el peso de mis penas / que no me dejaba andá». «Me dejan caé mis males, / quien me levante no encuentro. / ¡Mis caías son mortales!m.

17. Escogemos esta seguiriya por su carácter paradigmático: «jSoy esgrasiaíto, / jasta en el andá, / que los pasitos que pa elante doy / se me ban p'atrás!» 
correspondido lleva al amante a desear morir. Este afán puede presentarse incluso como una rebelión imposible contra el destino ${ }^{18}$. Sin embargo, muy en sintonía con la actitud romántica, predominan aquellos textos en los que el amante elige la soledad y el dolor como modo de vida. Es la exaltación del sufrimiento llevada a sus últimas consecuencias. El enamorado prefiere la muerte a la liberación. Se insiste en el ansia de morir, en una voluntad que implique no dejar de amar. Es un proceso de autoafirmación en el dolor, un dulce abandono, como el que nos evoca la poesía del amor cortés. No es el morir por desprecio al amado, sino el morir agradecido y complacido $^{19}$.

\section{EL MUNDO IRREAL ES VEROSÍMILMENTE UN MUNDO FEMENINO}

En la estética modernista de lo andaluz se muestra una insistencia cada vez mayor en la fatalidad del amor y en la melancolía femenina. Consideramos que la mujer andaluza representa más que otras manifestaciones finiseculares la fatalidad en que se unen el pecado y la tristeza. Es fundamental la figura de Carmen, cuya luz ilumina este imaginario. Su eco en la copla es profundo, no solo como mujer liberada, sino sobre todo como símbolo de resonancias atávicas y trágicas (González Troyano 1991, 27). A través de Carmen recrea la copla flamenca esta condición fatal femenina (García Gómez 1993, 98). La mujer del flamenco es la gitana, la dominadora de hombres que al tiempo debe aceptar su naturaleza de sufrimiento y caída. Es, por supuesto, la mujer de cabello negro, característica imagen de la femme fatale del fin de siglo.

Esta tristeza femenina, unida para siempre al cante jondo, presenta un gran desarrollo en la cultura modernista, en el teatro de Antonio y Manuel Machado o en la pintura de Julio Romero de Torres. Obras como Cante Hondo, La Copla o La Nieta de la Trini son generadoras de nuevas imágenes, de sublimación e idealización de la marginalidad flamenca. En La Lola se va a los puertos encontramos la identificación absoluta entre mujer y cante. No deja de ser «la Lola» la mujer fatal, la gitana que sufre, la mujer rodada que se libera a través del dolor y de la pena. Gracias a su vocación de sacrificio la cantaora adquiere un carácter sagrado. Como se nos dice en la obra de los

18. "Maldigo yo la hora, / que puse yo mis ojos en ti, / me tenía que haber muerto, / cuando yo te conocí. Recuérdese "Tus ojos negros" o "Limosna de amores".

19. "Tenedle, por Dios, clemencia, / piedad tenedle los jueces, / que yo le he dado licencia / para matarme cien veces». «La Ruiseñora». 
Machado, «La Lola no es de este mundo», «La Lola no es una mujer siquiera». Se trata de un imaginario que, junto al universo de García Lorca, tiene una notable incidencia en las creaciones de la canción española.

Con esta herencia cultural y artística, la canción dramatiza el motivo de la mujer cantaora. Ella se transforma en el sujeto protagonista. El punto de vista es plenamente femenino. El mundo flamenco se asocia en estas canciones a los malos ambientes, a la vida marginal y a la prostitución. Así lo vemos en «Dolores la Petenera», «Lola Puñales» o "La Ruiseñora». El café cantante permite una intensa presencia de erotismo y voluptuosidad. El café se une a los conflictos y a la vida amorosa de la cantaora, motivo de marginalidad que va a ser recreado en la propia dramaturgia, indumentaria y escenificación de la canción. Pero el flamenco también se une a la tragedia amorosa, destino de la cantaora, al color negro y, por consiguiente, a la melancolía. El cante toma un carácter sagrado, la misma espiritualidad que ha ido adquiriendo desde finales del XIX, y que ahora se proyecta sobre estas creaciones de autor. Significativa es la canción "Una cantaora", inspirada en la protagonista de La Lola se va a los puertos. Como en otras obras artísticas, la mujer permite la liberación de lo jondo a través del sufrimiento. Y no es extraño que sea así, puesto que lo sagrado sigue siendo en el fin de siglo un ámbito profundamente femenino. Creemos, en este sentido, que existe una canción que muestra de manera paradigmática esta vocación consoladora del cante. Se trata de «La Ruiseñora». Coincidimos con Sieburth cuando nos dice, a propósito de la cantaora, que «el flamenco no sólo expresa su talento natural, sino que también da voz a su profundo dolor emocional» (2014, 255).

Podemos considerar, por otro lado, una imagen femenina fuertemente inspirada en la copla flamenca, la mujer como sombra. Es una figura abstracta que no se describe, que no lleva nombre, cuyo cuerpo supone una amenaza. Solo se dan breves pinceladas desde un discurso masculino. No obstante, en la canción se muestra cierta presencia de la sensualidad. Aparecen los ojos y el cabello negro, con toda la carga de fatalismo que evocan. "Es la seductora que atrae a su presa con sus largos y ondulantes cabellos» (Litvak 1979, 3). Cabello negro, gitanismo y melancolía, aspectos que no pueden desligarse de la Andalucía melancólica de finales del XIX. Dicho modelo lo hallamos en canciones tan distantes en el tiempo como "Antonio Vargas Heredia», "Carcelero, carcelero» o "Vino amargo". Muy cercana a esta figura resulta la imagen de la mujer rodada ${ }^{20}$. Ella es gitana

20. «Por esos mundos / anda ella perdía / tantos consejitos como yo le daba / ninguno servía». «Qué desgracia es la mía / con quien vine a dar / con una hija de tan mala 
y errante, relacionada con la brujería. Este carácter rodado supone una amenaza de sexualidad. La gitana es la mujer errante, la que camina por el mundo arrastrándolo todo a su paso. Responde a la tradición de la mujer como provocadora del desorden, como vemos en «Manolo Reyes» O "Rosa venenosa».

Pero debemos hablar de una mujer que cobra vida en la canción española, se convierte en la voz focalizadora, e incluso narra en primera persona. La canción adopta, así, una perspectiva nueva y diferente respecto al flamenco. La gitana se hace visible, abandona a los suyos, se marcha errante por el mundo y sufre un castigo y soledad que la llevan al arrepentimiento. Nos referimos a las figuras femeninas de "No me quieras tanto", "María de la O", "Cárcel de oro» o "María Magdalena». Son mujeres caídas, con una gran fuerza sexual, transgresoras, ansiosas de vida y de camino. Es muy importante, como en Carmen, el deseo de libertad, aunque también, como en Carmen, está muy presente el fatalismo. El motivo de la mujer rodada es constante, asociado casi siempre a un ambiente de marginalidad. Sin embargo, existe en ellas una conciencia de culpa. Como en las creaciones de Romero de Torres, late la imagen de la prostituta arrepentida. Nos narran tales canciones el proceso de remordimiento de quien no quiere ser mujer rodada. Se nos presenta, desde una perspectiva bastante conservadora, el castigo de la sensualidad, característico de la época romántica y el fin de siglo. Resulta inevitable recordar aquí la figura de la mujer matadora que nos muestran canciones como "La guapa» o "Mañana sale». Aunque responda al imaginario finisecular de la mujer como ser perverso, no deja de ser una nueva vía de aceptación de la fatalidad. Presenta el carácter ambiguo de las representaciones femeninas de la época, pues, por un lado, es la femme fatal y, por otro, la mujer frágil que queda redimida por el amor que siente. En este camino de venganza que ella elige, se convierte en un ser sacrificado, melancólico y triste. No olvidemos la relación con las heroínas clásicas ni la herencia de la mujer matadora de nuestros romances. A pesar de la muerte, estas canciones manifiestan un dominio absoluto del amor y una redención a través de este.

Se trata de la gitana melancólica, "mujer que sufre y padece», muy cercana a las representaciones pictóricas de principios del siglo Xx. El pecado es una fatalidad. Sin embargo, a pesar de todo, ella es responsable de su destino. De acuerdo con la mentalidad romántica, se muestra una asociación constante de libertad y predestinación. El sufrimiento las lleva a pensar en el pecado para encontrar una explicación a su dolor. También

mare / harta de roar!» 
en los textos flamencos la mujer es consciente de una fatalidad que resulta ineludible. La poesía flamenca configura con más vehemencia que otras creaciones finiseculares una imagen artística femenina ligada al padecimiento $^{21}$. La mujer es el ser desgraciado. Fijémonos en la importancia que adquiere el hombre como redentor, frente a la debilidad intelectual de la mujer. En el contexto de misoginia en que se inspiran estas canciones, solo el amor del hombre las salva. Recordemos el fuerte simbolismo de «La Niña de fuegom. Se trata de una dramatización del proceso redentor de la gitana, fuertemente inspirado en la copla flamenca. Sin embargo, es la canción española la que nos muestra todo el proceso de castigo y redención. Como abstracción simbólica, la gitana cobra voz en la canción para responder al hombre con su desconsuelo.

\section{CONClusiones}

Son los poetas románticos y modernistas los creadores de la poesía flamenca como una nueva canción de soledad. Se concibe la copla como heredera de toda una tradición poética de carácter popular sobre la que se proyectan los rasgos esenciales del Romanticismo. Esta reinterpretación de la cultura andaluza trae consigo un alejamiento del flamenco de la realidad teatral y un distanciamiento de un género que a finales del XIX es denominado cuplé. En este sentido, las relaciones de flamenco y cuplé no solo son importantes por las sintonías que pueden existir entre ellos, sino también por esta voluntad de alejamiento que la literatura flamenca muestra desde los orígenes.

Sin embargo, a pesar de esta concepción intimista de lo popular, flamenco y cuplé siguen conviviendo en los escenarios teatrales. Gracias a intérpretes y autores particularmente unidos al flamenco, esta copla, de naturaleza modernista, comienza a ejercer una gran influencia en la canción orquestada. Así, el cuplé de principios de siglo revela poco a poco un carácter melancólico. Se inicia una andadura que culmina en la canción española de los años treinta. Con el auge de lo expresión neopopular y la presencia de poetas como Rafael de León, los textos flamencos constituyen una verdadera inspiración para estas canciones. Se proyecta sobre la canción, de manera particular, sobre la zambra, el carácter espiritual de

21. "La curpa tú las tenío / de la desgracia tan grande / que a ti misma te ha venío». "Si te llevaras de mis consejos / no llorarías como tú lloras, / ni te vieras tan desengañaíta / como tú te estás viendo ahora". 
la copla, así como la cultura flamenca generada por el modernismo, una realidad artística caracterizada por la noche, la sublimación del dolor y el protagonismo femenino, que apenas ha sido considerada.

El mundo de la copla flamenca es el mundo de lo nocturno. El estallido emocional del hombre ocurre siempre en la noche. De esta manera, el cante jondo en la canción española queda unido a la noche, a la mujer y al consuelo a través del arte. La heroína romántica es una cantaora. Con esta nueva lectura que la canción realiza de la poesía flamenca se recupera la tradición de la canción de espera femenina, pero desde unas coordenadas claramente modernistas. El amor es un sacrificio que se acepta desde la libertad. Existe toda una simbología ligada al martirio que no podemos separar del gusto de la época por la belleza mórbida y por la unión de erotismo y violencia. No obstante, canción y flamenco muestran una concepción extremadamente física del sufrimiento, un realismo también muy característico de la tradición literaria. En consonancia con esta sensibilidad romántica, hallamos una relación obsesionante entre mujer y melancolía, una condición trágica de lo femenino, muy influida por el mito de Carmen, desarrollada en una serie de imágenes que nos conducen desde su presencia virtual en el flamenco, la mujer contemplada desde el enfoque masculino, hasta su existencia en la canción española como mirada autónoma y focalización narrativa.

\section{BiBLIOGRAFÍA}

Argullol, Rafael. El héroe y el Único. El espíritu trágico del Romanticismo. Barcelona: Acantilado, 2008.

Balmaseda, Manuel. Primer Cancionero de Coplas Flamencas Populares según el estilo de Andalucía. Edición de Enrique Rodríguez Baltanás. Sevilla: Signatura, 2001 [1881].

BÉCQuer, Gustavo Adolfo. "La Soledad. Colección de cantares por Augusto Ferrán" En BéCQuer, Gustavo Adolfo. Rimas. Otros poemas. Obras en Prosa. Introducción, edición y notas de Leonardo Romero Tobar. Madrid: Espasa-Calpe, 2000 [1861]. Biblioteca de Literatura Universal.

Cansinos Assens, Rafael. La copla andaluza. Edición de Abelardo Linares. Editoriales Andaluzas Unidas, 1985 [1933].

CEnizo, José. La madre y la compañera en las coplas flamencas. Sevilla: Signatura, 2005.

DE PAZ, Alfredo. La revolución romántica: poéticas, estéticas, ideologías. Traducción de Mar García Lozano. Madrid: Tecnos, 1992.

DURAND, Gilbert. Las estructuras antropológicas del imaginario. Introducción a arquetipología general. Madrid: FCE, 2005. 
GARCía Gómez, Génesis. Cante flamenco, cante minero: una interpretación sociocultural. Barcelona: Anthropos, 1993.

GARCía LORCA, Federico. "Importancia histórica y artística del primitivo canto andaluz llamado Cante Jondo». En Obras Completas. Edición de Miguel García Posada. Madrid: Galaxia Gutenberg, tomo III, 1996 [1922], pp. 1281-1303.

GARCía LORCA, Federico. "Juego y teoría del duende». En Obras Completas. Edición de Miguel García Posada. Madrid: Galaxia Gutenberg, tomo III, 1996 [1933], pp. $150-162$.

GonZÁlez Troyano, Alberto. La desventura de Carmen: una divagación sobre Andalucía. Madrid: Espasa-Calpe, 1991.

GuRMÉnDEZ, Carlos. La melancolía. Madrid: Espasa-Calpe, 1994.

Gutiérrez CARBajo, Francisco. La copla flamenca y la lírica de tipo popular. Madrid: Cinterco, 2 vols., 1990.

Hebreo, León. Diálogos de amor. Madrid: Editorial Tecnos, 2002 [1535]. Colección Neometrópolis.

Jiménez, Juan Ramón. Alerta. Texto preparado por Javier Blasco, prólogo de Armando Romero. Madrid: Visor, 2010.

León, Rafael de. Poemas y canciones de Rafael de León. Edición de Josefa Acosta Díaz, Manuel José Gómez Lara y Jorge Jiménez Barrientos. Con índice de temas y motivos amatorios de Antonio Ramírez de Verger. 3. ${ }^{a}$ edición. Sevilla: Alfar, 1997.

LiTVAK, Lily. Erotismo, fin de siglo. Barcelona: Antoni Bosch, 1979.

LITVAK, Lily. "El reino interior. La mujer y el inconsciente en la pintura simbolista». En López Fernández, María y Valeriano Bozal (eds.). Mujeres pintadas: la imagen de la mujer en España 1890-1914 (exposición). Madrid: Fundación Cultural Mapfre Vida, 2004, pp. 58-77.

LunA, Inés María. "El flamenco como expresión de lo sublime: la colección de cantes flamencos de Antonio Machado y Álvarez». En DíAz BáÑEz, José Miguel, Francisco Javier ESCOBAR BORREGO e Inmaculada VENTURA (eds.). Las fronteras entre los géneros: Flamenco y otras músicas de tradición oral. Actas del III Congreso de Investigación y Flamenco. Sevilla: Universidad de Sevilla, 2012, pp. 97-104.

Machado, Manuel. Poesías completas. Edición de Antonio Fernández Ferrer. Sevilla: Renacimiento, 1993.

Machado y Álvarez, Antonio. Colección de cantes flamencos. Obras Completas. Edición, introducción y notas de Enrique Rodríguez Baltanás. Sevilla: Diputación de Sevilla-Fundación Machado, 2005 [1881].

MAURER, Christopher. Lorca y su "Arquitectura del cante jondo». Albolote: Comares, 2000.

Ortega y Gasset, José. Estudios sobre el amor. Madrid: Alianza, 2009 [1939].

PRAz, Mario. La carne, la muerte y el diablo en la literatura romántica. Barcelona: Acantilado, 1999 [1930].

Reyes Cano, Rogelio. "Bécquer y el mundo de los sueños". Boletín de la Real Academia Sevillana de Buenas Letras: Minervae Baeticae, 2007, 35, pp. 127-148. 
RODRÍGUEZ BALTANÁs, Enrique. "Las soleares: una sebnsucht a la andaluza (origen romántico y difusión europea de la canción de soledad)». En PIÑERO RAMíREZ, Pedro M. (ed.). De la canción de amor medieval a las soleares. "Profesor Manuel Alvar in memoriam", Lyra Minima Oral. Sevilla: Publicaciones de la Universidad de Sevilla-Fundación Machado, 2004, pp. 573-580.

SieburTh, Stephany. Coplas para sobrevivir. Conchita Piquer, los vencidos y la represión franquista. Madrid: Cátedra, 2014. 